\title{
Application of Project Management Framework into the Simulation of International Commodity Exhibition on Campus
}

\author{
H. W. Ker*, J. Y. Yang \\ Department of International Trade, Chihlee Institute of Technology, Wunhua Rd., Banciao District, New Taipei City, Taiwan \\ *Corresponding Author: hker@mail.chihlee.edu.tw
}

Copyright (C) 2013 Horizon Research Publishing All rights reserved.

\begin{abstract}
Emphasizing on exhibition industries can bring multiplier effects on benefits of corporations. To comply with the trend and to meet the skills and knowledge demanded by the workforce, the Department of International Trade of C Institute of Technology establishes a Simulation of International Commodity Exhibitionto provide students with practical experience in organizing an international commodity exhibition, integrating the curriculum what they have learned, and solving the problems they may face in the future workplace.However, a systematic procedure, based on the integration of information available, past experiences, and experts' knowledge, has not been developed for this important activity. The practice of organizing exhibition and project management shares a lot of common characteristics. This paper aims to (1)examine the advantages of applying project management to the simulation of international commodity exhibition on campus, (2) suggest the practical application of project management in this simulation of exhibition on campus, including five processes and nine knowledge areas, and thus (3) provide Department with reference, and to avoid repetitive planning. Results suggested that simulation of commodity exhibition on campus should focus on the knowledge areas such as Human Resource Management, Integration Management, Communication Management, and Time Management. Further suggestions are given.
\end{abstract}

Keywords Project Management, Simulation of Commodity Exhibition, Human Resource Management, Integration Management, Communication Management, Time Management

\section{Introduction}

In the fierce competition of global business,international commodity exhibitions are used widely in many countries to expand international business, promote marketing, drive economic development, and construct regional competitiveness. School education, especially activities and curricula in technical institutions, has to meet the needs of workplaces. Schools have to teach students the knowledge and skills that workplaces demand. In order to comply with this trend,the Department of International Trade of $\mathrm{C}$ Institute of Technology establishes a Simulation of International Commodity Exhibition on campus, which requires all juniors planning and executing an international commodity exhibition on campus. Commodity presented/sold in this exhibition has to be import or export goods, rather than those goods only circulate locally. This exhibition simulates all the processes that an international commodity exhibition in a real-world should have. In such ways, students can understand all the procedures needed in importing or exporting goods, which are the main skills and knowledge a student in the Department of International Trade should learn and experience.

The Department designs the curricula and activities based on the knowledge and skills required for the careers related to international trade, for example, marketing, management, and import and export business. The goals of this activity are to provide students with practical experience in learning all the processes in organizing an international commodity exhibition, to integrate the curricula what they have learned, and solve the problems they may face in the future workplaces. The curricula students have to integrate include English, marketing research, statistics, convention and exhibition service, database management, network marketing and application, English presentation skills, and the practice of international trade. Students perform this exhibition as "learning by doing", which is the core concept in this activity.

Although the Department has run this simulation of commodity exhibition on campus for more than twenty-five years, a systematic procedure, based on the integration of information available, past experiences, and experts' knowledge, has not been developed.The simulation of 
exhibition itself has the characteristics of project management, which has firmly beginning and end, is task-oriented, and has specific goals, output, service or results.Project management is the integration of planning, organizing, securing, and managing resources to achieve predefined specific goals [1].

The knowledge and techniques of project management have been widely used in many enterprises and professional areas to make project execution more efficiently and effectively.Project management is divided into five processes and nine knowledge areas. Although the organization of an international exhibition is a highly complicated process, the practice of organizing exhibition and project management share a lot of common characteristics.However, as mentioned above, the simulation of exhibition is not planned or implemented by uses of the practice of project management. This paper aims to (1)examine advantages of applying project management into simulation of international commodity exhibition on campus, (2) suggest the practical application of project management in this simulation of exhibition on campus, including five processes and nine knowledge areas, and thus (3) provide the Department of International Trade with reference, to avoid repetitive planning, and consider to introduce project management framework into simulation of international commodity exhibition on campus for preparation and execution.

\section{Literature Review}

Project management is the application of various knowledge, skills, tools, and techniques to fulfill project requirements. Project Management Institute [2] defined projects as temporary team activities to get a unique product, service or results. The word temporary means that the project has a predefined start and end in time and make use predefined scopes and resources to fulfill project goals. The word unique expresses that a project is not a routine process, but a set of operations designed uniquely to accomplish project goals. A project team may be from different organizations located in geographical areas. According to these features, PMI defined project management as "is the application of knowledge, skills and techniques to execute projects effectively and efficiently. It's a strategic competency for organizations, enabling them to tie project results to business goals - and thus, better compete in their markets".

The professional project management book published by PMI [3]-PMI'sA Guide to the Project Management Body of Knowledge $\left(\mathrm{PMBOK}^{\circledR}\right.$ Guide) identifies the five processes for project management as: Initiating, Planning, Executing, Monitoring and Controlling, and Closing. The nine knowledge areas for project management are Integration, Scope, Time, Cost, Quality, Procurement, Human Resources, Communications, and Risk Management. All nine knowledge areas have its specific stages and every stage has its own input, tools and technologies, and output. The five processes and nine knowledge areas are briefly stated as follows.

(1). Initiating: The initiating processes define the natures and scopes of the project [4]. This is the key stage of beginning a project. The key tasks including in the initiating stage are: (i) analysis of project requirements in measurable goals, (ii) analysis of costs, benefit, and budgets, (iii) stakeholder analysis, and (iv) project charter such as tasks, costs, and deliverables.

(2). Planning: This process is to plan time, risk, cost and resources adequately to estimate the work needed to effectively execute project execution. Kerzner [5] suggests the tasks of planning may consists of: (i) developing the scope statement, (ii) selecting the planning team members, (iii)identifying deliverables, (iv)creating the work breakdown structure (WBS), (v) estimating resource requirement, time, and cost for activities, (vi) developing activity schedule, (vii) risk planning, (viii) planning for communication and scope, and (ix)identifying roles and responsibilities.

(3). Executing: This stage consists of the work defined in project plans to accomplish the project's goals. This process integrates and implements the activities of the project according with the project management plan [6].

(4). Monitoring and Controlling: This process observes project execution so that potential problems can be identified earlier and corrections can be taken in advance. Lewis [7] suggest this process may include (i) measuring the ongoing tasks, (ii)monitoring the factors (e.g.,cost, effort, or scopes) may have adverse effects on plans and project performance baselines, (iii) determining the preventive corrective actions and risks, and (iv) making sure only the approved changes are executed. PMI [3] also suggests that for project maintenance, the tasks should include continuing support of users and updating software as well as error corrections.

(5). Closing: This phase includes the formal acceptance of deliverables and ends the project. Administrative activities consist of archiving all the files of project and documenting lessons learned. PMI [3] states the work of this stage is: (i) project close: finalize all activities across all of the process to formally close the project, and (ii)contract closure: complete and settle all contracts.

The relationship between five processes, and nine knowledge areas and their tasks can be summarized as Table 1. It should be noted that not every knowledge area has all five processes. For example, Scope knowledge area only occurs in planning, and monitoring and controlling processes. Human Resource knowledge area happens in planning, and executing processes. Purchase knowledge area takes place in planning, executing, monitoring and controlling, and closing processes. The only knowledge area appears in all five processes is Integration Management.

Among the nine knowledge areas, Time, Cost, and Scope are constraints in implementing a project and also the most 
influential factors for the success of a project. Traditionally they are so called "Project Management Triangle" because one side of changes will affect the others [8]. Increasing scopes would increase time and cost. A tight schedule implies increasing costs and reducing scopes. A tight budget could increase time and reduce scope. Project teams have to plan their work to meet these three constrains to ensure projects can be completed within scheduled time and the limited budget while achieve the predefined results.

In summary, project management is to develop a project plan. The content should consist of defining and confirming the project goals and outcomes, identifying tasks/activities to achieve goals, quantifying the resources needed and availabilities, and determining budgets and timelines for completion. It also includes managing the fulfillment of the project plans, and monitoring and controlling the on-going processes to ensure that performances meet the quality assurance. Project team members have to establish lessons learned at the closure of a project.

\section{Methods}

This study uses in-depth interview and content analysis to investigate the key knowledge areas needed for simulation of commodity exhibition on campus. The interviewees are the project management professionals in industries of conventions and exhibitions. They are all in top positions in their companies, and all have a lot of experience in utilizing project management skills and techniques in organizing projects, such as international conference and exhibition, and software design and development in project management. Table 2 is the profiles, including positions and responsibilities, of the interviewees for this study.

Table 1. Summary of Relationship between five processes and nine knowledge areas

\begin{tabular}{|c|c|c|c|c|c|}
\hline \multirow{2}{*}{$\begin{array}{l}\text { Nine } \\
\text { knowledge } \\
\text { areas }\end{array}$} & \multicolumn{5}{|l|}{ Five processes } \\
\hline & Initiating & Planning & Executing & Monitoring and Controlling & Closing \\
\hline Integration & $\begin{array}{l}\text { Develop project } \\
\text { Charter }\end{array}$ & $\begin{array}{l}\text { Development project } \\
\text { management plan }\end{array}$ & $\begin{array}{l}\text { Guidance and management of } \\
\text { project implementation }\end{array}$ & $\begin{array}{l}\text { Monitor project work } \\
\text { Implementation of integrated } \\
\text { change control }\end{array}$ & $\begin{array}{l}\text { Close a } \\
\text { project or } \\
\text { phase }\end{array}$ \\
\hline Scope & & \begin{tabular}{|l|} 
Gather requirements \\
Define areas \\
The establishment of WBS
\end{tabular} & & $\begin{array}{l}\text { Verification area } \\
\text { Control area }\end{array}$ & \\
\hline Time & & \begin{tabular}{|l|} 
Defining activities \\
Sorting activity \\
Estimate activity resources \\
Estimate activity-history \\
Development time
\end{tabular} & & Control time & \\
\hline Cost & & $\begin{array}{l}\text { Estimated cost } \\
\text { Decide budget }\end{array}$ & & Control costs & \\
\hline Quality & & Planning quality & $\begin{array}{l}\text { Implementation of quality } \\
\text { assurance }\end{array}$ & $\begin{array}{l}\text { Implementation of quality } \\
\text { management }\end{array}$ & \\
\hline $\begin{array}{l}\text { Human } \\
\text { Resources }\end{array}$ & & $\begin{array}{l}\text { Planning human resources } \\
\text { plan }\end{array}$ & $\begin{array}{l}\text { Access to project team } \\
\text { Development project team } \\
\text { Manage project team }\end{array}$ & & \\
\hline Communication & $\begin{array}{l}\text { Identification of } \\
\text { interested persons }\end{array}$ & Planning communications & $\begin{array}{l}\text { Publishing information } \\
\text { Managing stakeholder } \\
\text { expectations }\end{array}$ & Report performance & \\
\hline Risk & & $\begin{array}{l}\text { Planning and risk } \\
\text { management } \\
\text { Identification of risk } \\
\text { Perform qualitative risk } \\
\text { analysis } \\
\text { Perform a quantitative risk } \\
\text { analysis } \\
\text { Plan risk responses }\end{array}$ & & Monitor risks & \\
\hline Purchase & & Procurement planning & The procurement & Management procurement & $\begin{array}{l}\text { closure of } \\
\text { procurement }\end{array}$ \\
\hline
\end{tabular}


Mainly there are four dimensions in the questionnaire: personnel training, software utilization, techniques and knowledge needed for the jobs related to exhibition, and the application of project management in exhibition. The contents of interview are originally organized into verbatim transcripts. These verbatim transcripts are further analyzed by techniques of content analysis, which primary and secondary parameters are coded based on the main concepts of these verbatim transcripts, and further appropriately separate into the nine knowledge areas. The frequencies and percentages of secondary parameters are then counted to signify the importance of each parameter. The total frequencies and percentages are computed to represent the weights of knowledge areas in application of project management in exhibition.

Table 2. Profiles of interviewees

\begin{tabular}{|c|c|c|}
\hline Interviewee & Title & Main Responsibilities \\
\hline $\mathrm{A}$ & Director & International Conference, exhibition planning and implementation \\
\hline $\mathrm{B}$ & Director & Marketing business \\
\hline $\mathrm{C}$ & Project Manager & Meetings, events, exhibition planning and execution \\
\hline $\mathrm{D}$ & Project Manager & Planning the Flower Expo \\
\hline $\mathrm{E}$ & General Manager & Software design and development, business E Systems implementation, project management \\
\hline $\mathrm{F}$ & Manager & Expanding business, planning enforcement, education and training \\
\hline
\end{tabular}

Table 3. The parameters of content analysis, frequencies and percentages of each parameter

\begin{tabular}{|c|c|c|c|c|c|c|}
\hline Knowledge Area & Primary Parameter & Second Parameters & Frequency & Percentages & Total Frequency & Total Percentages \\
\hline \multirow{17}{*}{$\begin{array}{l}\text { Human resource } \\
\text { management }\end{array}$} & \multirow{10}{*}{ Personnel training } & Learning by doing & 2 & $1.07 \%$ & \multirow{17}{*}{69} & \multirow{17}{*}{$36.90 \%$} \\
\hline & & Practical learning & 1 & $0.53 \%$ & & \\
\hline & & Marketing methods & 4 & $2.14 \%$ & & \\
\hline & & Attitude of service & 1 & $0.53 \%$ & & \\
\hline & & Integration abilities & 1 & $0.53 \%$ & & \\
\hline & & Pre-training & 4 & $2.14 \%$ & & \\
\hline & & $\begin{array}{c}\text { Profession } \\
\text { development }\end{array}$ & 2 & $1.07 \%$ & & \\
\hline & & Professional training & 3 & $1.60 \%$ & & \\
\hline & & Resources & 1 & $0.53 \%$ & & \\
\hline & & Attitude & 3 & $1.60 \%$ & & \\
\hline & \multirow{7}{*}{ Roles and responsibilities } & Skills & 15 & $8.02 \%$ & & \\
\hline & & Role assignment & 9 & $4.81 \%$ & & \\
\hline & & Basic skills & 6 & $3.21 \%$ & & \\
\hline & & Professionals & 1 & $0.53 \%$ & & \\
\hline & & Lack of professional & 5 & $2.67 \%$ & & \\
\hline & & Liability issues & 4 & $2.14 \%$ & & \\
\hline & & Flexibilities & 7 & $3.74 \%$ & & \\
\hline \multirow{3}{*}{ Cost management } & \multirow{3}{*}{$\begin{array}{l}\text { Development of budget } \\
\text { principles }\end{array}$} & Activities resources & 2 & $1.07 \%$ & \multirow{3}{*}{5} & \multirow{3}{*}{$2.67 \%$} \\
\hline & & Sources of funding & 1 & $0.53 \%$ & & \\
\hline & & Budget & 2 & $1.07 \%$ & & \\
\hline \multirow{8}{*}{$\begin{array}{c}\text { Communication } \\
\text { management }\end{array}$} & \multirow{7}{*}{ Stakeholders } & PM & 2 & $1.07 \%$ & \multirow{8}{*}{26} & \multirow{8}{*}{$13.90 \%$} \\
\hline & & staff & 1 & $0.53 \%$ & & \\
\hline & & Leader & 3 & $1.60 \%$ & & \\
\hline & & Manufacturers & 2 & $1.07 \%$ & & \\
\hline & & Students & 1 & $0.53 \%$ & & \\
\hline & & Customers & 1 & $0.53 \%$ & & \\
\hline & & Specific groups & 1 & $0.53 \%$ & & \\
\hline & Communication method & $\begin{array}{c}\text { Customer } \\
\text { communication }\end{array}$ & 1 & $0.53 \%$ & & \\
\hline
\end{tabular}




\begin{tabular}{|c|c|c|c|c|c|c|}
\hline Knowledge Area & Primary Parameter & Second Parameters & Frequency & Percentages & Total Frequency & Total Percentages \\
\hline & & $\begin{array}{l}\text { Coordination of third } \\
\text { party }\end{array}$ & 2 & $1.07 \%$ & & \\
\hline & & Group coordination & 1 & $0.53 \%$ & & \\
\hline & & $\begin{array}{c}\text { Unable to effectively } \\
\text { communicate } \\
\text { information }\end{array}$ & 1 & $0.53 \%$ & & \\
\hline & & $\begin{array}{c}\text { Means of } \\
\text { communication }\end{array}$ & 2 & $1.07 \%$ & & \\
\hline & & Communication skills & 6 & $3.21 \%$ & & \\
\hline & & \begin{tabular}{|c|}
$\begin{array}{c}\text { Problem-solving } \\
\text { abilities }\end{array}$ \\
\end{tabular} & 2 & $1.07 \%$ & & \\
\hline \multirow{4}{*}{ Scope management } & \multirow{4}{*}{ Demand collection } & $\begin{array}{c}\text { Exhibition and } \\
\text { Government policies }\end{array}$ & 1 & $0.53 \%$ & \multirow{4}{*}{7} & \multirow{4}{*}{$3.74 \%$} \\
\hline & & $\begin{array}{l}\text { International } \\
\text { exhibition } \\
\text { requirements } \\
\text { document } \\
\end{array}$ & 1 & $0.53 \%$ & & \\
\hline & & Government support & 3 & $1.60 \%$ & & \\
\hline & & $\begin{array}{c}\text { Lack of policy } \\
\text { support }\end{array}$ & 2 & $1.07 \%$ & & \\
\hline \multirow{2}{*}{ Quality management } & \multirow{2}{*}{ Quality management } & After-sales service & 1 & $0.53 \%$ & \multirow{2}{*}{8} & \multirow{2}{*}{$4.28 \%$} \\
\hline & & Customer satisfaction & 7 & $3.74 \%$ & & \\
\hline \multirow{3}{*}{ Risk management } & \multirow{3}{*}{ Risk management } & Unknown risk & 7 & $3.74 \%$ & \multirow{3}{*}{14} & \multirow{3}{*}{$7.49 \%$} \\
\hline & & Risk prevention & 6 & $3.21 \%$ & & \\
\hline & & Forecast risks & 1 & $0.53 \%$ & & \\
\hline \multirow{6}{*}{ Time management } & \multirow{3}{*}{ Activities resources } & $\begin{array}{c}\text { Application of } \\
\text { software and new } \\
\text { technology } \\
\end{array}$ & 4 & $2.14 \%$ & \multirow{6}{*}{23} & \multirow{6}{*}{$12.30 \%$} \\
\hline & & Lack of resources & 5 & $2.67 \%$ & & \\
\hline & & $\begin{array}{c}\text { Resource allocation is } \\
\text { not perfect }\end{array}$ & 1 & $0.53 \%$ & & \\
\hline & \multirow{3}{*}{ Control time } & Time control & 1 & $0.53 \%$ & & \\
\hline & & Flow of execution & 7 & $3.74 \%$ & & \\
\hline & & Control time & 5 & $2.67 \%$ & & \\
\hline \multirow{12}{*}{$\begin{array}{l}\text { Integration } \\
\text { management }\end{array}$} & \multirow{3}{*}{ Develop project Charter } & Market trends & 2 & $1.07 \%$ & \multirow{12}{*}{35} & \multirow{12}{*}{$18.72 \%$} \\
\hline & & Strategies & 2 & $1.07 \%$ & & \\
\hline & & $\begin{array}{c}\text { Responsibility-oriente } \\
\text { d }\end{array}$ & 2 & $1.07 \%$ & & \\
\hline & \multirow{4}{*}{ Lessons learned } & \begin{tabular}{|l|} 
documents \\
\end{tabular} & 1 & $0.53 \%$ & & \\
\hline & & experiences & 6 & $3.21 \%$ & & \\
\hline & & Knowledge base & 1 & $0.53 \%$ & & \\
\hline & & Practical application & 13 & $6.95 \%$ & & \\
\hline & \multirow{4}{*}{ evaluation } & Settle revenue & 1 & $0.53 \%$ & & \\
\hline & & review & 1 & $0.53 \%$ & & \\
\hline & & $\begin{array}{c}\text { Techniques for } \\
\text { review }\end{array}$ & 2 & $1.07 \%$ & & \\
\hline & & Marginal benefit & 2 & $1.07 \%$ & & \\
\hline & Implementation & $\begin{array}{c}\text { Techniques/tools for } \\
\text { implementing } \\
\text { projects } \\
\end{array}$ & 2 & $1.07 \%$ & & \\
\hline
\end{tabular}




\section{Result}

As aforementioned, interview contents are further investigated by means of content analysis. Table 3 shows the parameters of content analysis, frequencies and percentages of each parameter.

Table 3 presents that the interviewees suggest that simulation of commodity exhibition on camps should focus on the knowledge areas such as Human Resource Management, Integration Management, Communication Management, and Time Management. The total percentages are $36.90 \%, 18.72 \%, 13.90 \%, 12.30 \%$, respectively. The results from in-depth interviews are summarized as follows:

(1). In Human Resources Management, focuses are on personnel training, and roles and responsibilities. The important elements include professional/basic skills,role assignments, liability issues, pre-training, and adaptability for the challenging work.

(2). In Integration Management, focuses are on developing project charter, lessons learned, evaluation, and implementation. The main components are applying known-knowledge efficiently, making use of lessons learned effectively, practical application and experience, techniques/tools for implementing projects, and possible marginal benefits.

(3). In Communication Management, emphases are on stakeholders, and particular communication skills and methods. Effective communication with stakeholders is particularly important for a successful project. Other important factors are effective communication skills, problem-solving skills, and coordination with team members.

(4). In Time Management, the main points are resources and time control. The main elements are lack of resource, application of software and new technology, and developing schedule and controlling schedule. The tasks have to be implemented on time.

\section{Conclusion and Recommendations}

Nowadays, emphasizing on exhibition industries can bring multiplier effects on benefits of corporations. According to the results from this study, it can be found that project management is an efficient tool in planning, executing, and monitoring an exhibition. An exhibition in nature is a project, which means it is a one-time effort to produce a specified outcome within a predetermined time. Project management is elaborately planned and organized effort to accomplish a successful exhibition.

This study examines the application of project management practice into campus commodity exhibition. Conclusions and recommendations are as follows:
(1). The importance of lessons learned: the Department should establish a platform for this simulation of exhibition. The contents inside this platform include community discussion, previous exhibition archives, $\mathrm{Q}$ and $\mathrm{A}$ classification, and manufacturers' information.

(2). The design of Curriculum and extracurricular activities should help to develop students' attitude toward work,interpersonal skills, and professional skills training.

(3). School education should help students to achieve proper methods in handling conflict, interpersonal communication skills, and coordination with team members.

Upon entering the exhibition career, most students will find that skills and knowledge they learned from schools are not adequate for their work. To narrow the gap between school education and workplaces, practice of project management must be integrated into the school curricula and activities. For example, training should include the cultivation of students' attitude toward work, professional skills training, tools and technologies of time management and communication. At the same time, school activities and curriculum contents must be in conjunction with industry requirements so that students can enhance their competence for future careers.

\section{REFERENCES}

[1] Wikipedia, Project management. Retrieved March 2, 2012, from http://en.wikipedia.org/wiki/Project_management\#cite_note21

[2] Project Management Institute, What is project management? Retrieved March 2, 2012, from

http://www.pmi.org/About-Us/About-Us-What-is-Project-M anagement.aspx

[3] PMI, A Guide to the Project Management Body of Knowledge, PA: Institute of Project Management, 2010.

[4] P. Nathan, G. E. Jones, PMP certification for dummies. NJ: John Wiley \& Sons, 2003.

[5] H. Kerzner, Project Management: A Systems Approach to Planning, Scheduling, and Controlling, NJ: John Wiley \& Sons, 2003.

[6] Wikipedia, Project management. Retrieved March 1, 2012, from http://en.wikipedia.org/wiki/Project_management

[7] J. P. Lewis, The project manager's desk reference: A comprehensive guide to project planning, scheduling, evaluation, and systems, NY:McGraw-Hill, 2000.

[8] P. McGhee,\& P. McAliney, Painless Project Management: A Step-by-Step Guide for Planning, Executing, and Managing Projects. Hoboken, NJ: John Wiley \& Sons, 2007. 